\title{
The Witch: A History of Fear From Ancient Times to the Present
}

Review Number: 2185

Publish date: Thursday, 26 October, 2017

Author: Ronald Hutton

ISBN: 9780300229042

Date of Publication: 2017

Price: $£ 25.00$

Pages: 376pp.

Publisher: Yale University Press

Publisher url: http://yalebooks.co.uk/display.asp?K=9780300229042

Place of Publication: London

Reviewer: Willem de Blécourt

This is an extremely ambitious, thought-provoking, challenging and inspiring book. It is informed by Hutton's earlier books (1), but it is also a culmination of his work over the last 15 years. (2) It is meticulously researched and it does not shy away from very broad chronological sweeps; it summarises studies on witchcraft and magic from the ancient to the early modern period (the 'present' in the subtitle is misleading, as is the subtitle as a whole), while setting out the lines for possible new investigations. But, alas, at the same time this book is deeply dissatisfying, even troubling, as it sometimes uncritically accepts received opinion. Moreover, it adheres to debatable assumptions about the use of anthropology in historical research and often lacks contextualisation. Lastly, the author keeps circling around his main subject, the witch, without ever homing in on her. Unfortunately a review like this cannot do justice to the wealth of ideas and research contained in this book.

Hutton starts his discussion by outlining five characteristics of the European witch and the way these can be found worldwide. He suggests that this provides a common model on the basis of which historians and anthropologists can collaborate and obtain interactive insights. 1 . A witch causes harm by uncanny means; 2. A witch is an internal threat to a community; 3. A witch works within a tradition; 4. A witch is evil; and 5. A witch can be resisted. These features produce a lot of variation taken from anthropological research. In passing Hutton introduces 'service magicians' as a new term for 'cunning folk', denoting magical specialists who were fighting against, or were consulted to help with, cases of malicious witchcraft. The advantages of Hutton's approach are that it strips 'witchcraft' to its bare essentials without contamining it with, for instance, possession, divination, shamanism, pagan religion, satanism, or 'occultism' in general. He proceeds to discuss ancient magic and witchcraft in Egypt, Mesopotamia, Greece and Rome and pays particular attention to the 'demonesses of the night', in a global context. The third chapter is dedicated to shamanism, and focuses on adjusting and refuting Carlo Ginzburg's theories on the subject.(3)

The second part of the book deals with the continental European perspectives, from ceremonial magic in chapter four, via the so-called 'hosts of the night' in chapter five, to the medieval trials, mostly against 'alleged' individual practitioners of witchcraft. I would note that I find group trials to be of dubious provenance.(4) Chapter six contains yet another description of the Alpine trials in the early 15th century. Hutton claims that the very first new witch trials occurred as early as 1424 in the Aney Valley in the 
Pyrenees and in Rome (p. 170-1), but this is debatable as he omits the Piedmont trials during the late 14th century. The last chapter in this part briefly discusses witch trials as they were held in the early-modern period and it finishes with the question of how real was the pact with the devil. As Hutton phrases it: 'there is, after all, ample apparent first-hand evidence on record that people worked witchcraft in partnership with demons whom they worshipped, and no objective means of proving conclusively that all of it is false. We simply decide to reject it as anything other than a fiction or a metaphor. This is an area of enquiry in which no academic investigator ever goes native (...)' (p. 207-8).

The third and last part of the book, already announced in chapter six (p. 158-61), zooms in on British topics: how witches relate to fairies, why there were fewer witch trials in Celtic areas than elsewhere on the British isles, and how the typical English witch's familiar came to be. In the following, I will restrict my discussion to what I regard as the main issues and will leave comments on entire chapters (on antiquity, or shamanism) to those more versed in these specific parts of the material; I will discuss the so-called 'night-flights' elsewhere.(5) [2]

Hutton's use of the results of anthropological fieldwork may well be approached from the way he applies European 'folklore' in his arguments. In his treatment, he contrasts these two, as he does not deal with anthropological research within Europe. Anthropologists only became active in the 20th century, which implies that Hutton's 'global context' is historically uneven, considering that the notion of 'contemporary ancestors' has long been discarded by anthropologists. As Hutton states firmly, the results of modern folklore research cannot be projected back in time. Criticising Jacob Grimm, he calls his brand of mental archaeology, 'a deeply patronizing attitude, which greatly underestimated the dynamic and creative aspects of popular culture' (p. 126), a stance I fully agree with.(6) Yet Hutton believes that the reports of anthropologists can provide an analytical frame for historical witchcraft, which basically means that they are considered as contemporaneous with the early-modern, or even more remote past. This approach, however, is flawed since the range of variants and possibilities Hutton sources from anthropologists have, like folklore, a history, too, and by neglecting this his points of reference are rendered false and may as well have been taken from novels or films. Societies visited by anthropologists were far from frozen in time but had already experienced the influx of western 'civilisation' and its informants were in an inferior position to the enquiring anthropologists. Hutton must have been aware of the problem (although he does not voice it), as he presents several examples of witch hunting before colonisation (p. 27), but without critiquing their sources. In my view, the first question to ask, for instance, about the Tswana (Botswana) night-witches, is in what way they could have derived from European demonology, given that they were 'treated as more or less fictional' (p. 67). I would also regard any group activity with suspicion, especially reports of incest and exhumation of corpses (p. 22-3), which seem to derive straight from the early European trials. Another example is the witch-finding technique of looking into a bowl of consecrated water, as was the custom in Zambia (p. 26), but also in Europe from at least the 16th century onwards. In my opinion, it is up to the author to prove that an almost world-wide occurrence of witchcraft was without European influences, but Hutton simply concludes that the 'European development of witchcraft beliefs (...) was to have knock-on effects upon the rest of the globe' (p. 41) without going into much detail, although the 1830s case of the Malagasy queen who prosecuted witches 'using early modern European Christian models' (p. 31) may be relevant here. The baptisms of indigenous Jehovah's witnesses, mentioned on the same page, look remarkably like the European water test. Those examples of European colonial influence can perhaps stand for hundreds of other cases.

The extra-European modern examples of witchcraft can, according to Hutton, be of value 'for an understanding of early modern mind-sets and the witch trials that these generated' and provide a number of clues for the European cases, such as fluctuations in the intensity of witch hunting and the presence of different magical practitioners (p. 43). I very much doubt this. The study of European cunning folk ('service magicians') was certainly inspired by anthropological research, but at the same time this research can in no way substitute for an understanding of European history - nor even help it, because it only creates unnecessary complications. It is circuitous to use extra-European material that has a possible European pedigree, but also its own history, to explain European mentality. Would it not have been better to use actual 
European material instead? Of course, Hutton's perspective is not without precedent (7) and many anthropologists made a similar mistake by neglecting 20th-century witchcraft research in Europe (with the exception of the extraordinary work by Favret-Saada, but without adhering to her approach of witchcraft as discursive).(8) The other issue is whether a 'global context' can actually aid understanding of local witchcraft, as it decontextualises local utterances, even if they can all be confidently translated as 'witchcraft' (or 'sorcery').

From any other than a British point of view, the five characteristics of the witch are historically inaccurate since Hutton has reserved the place of the devil only for the discussion of his fourth characteristic, the witch's evilness. As Hutton sets out to explain European witch trials, the devil should have absolute priority; apostasy, rather than witches causing harm, was the central ingredient in the trials spreading across Europe from the 15th century onwards. The characteristics are also incomplete, as they overlook the profiteering (male) witch as found on the European continent, in particular in the eastern Netherlands and adjacent northwestern Germany up to Holstein.(9) As the word for male witch functioned as an insult of one individual by another, this witch figure was unlike the feminised male witch discussed by demonologists.(10) This witch was also far removed from the cunning man (or 'service magician') who operated on a regional level, had nothing to do with shamans, and did not belong to the group of male witches that could be found in a trial, accused of having attended a sabbat. Whether these men 'caused harm by uncanny means' is unclear (they were unlikely to have been thought to do so), thus their historical presence falls outside Hutton's scope. The claim that in the 'Germanic cultural zone' 'the majority of those accused in this region were women' (p. 203) thus depends on the kind of source used. To put it more accurately, when it comes to gender, criminal trial sources may offer a distorted view of accusations in every-day life. But slander trials have hardly been used as a source for British witchcraft and may well turn up a different kind of witch than the criminal trial sources.

The sheer breadth of The Witch is both its strength and its weakness. Hutton gives little thought to processes of distribution; the concept of acculturation appears too late, and only when it concerns Wales (p. 270), although earlier he uses the term 'borrowing' (p. 30). The author's ploy to explain the introduction of the witch trials by the earlier state of witchcraft in a country is fascinating. It can, however, only be part of the reason criminal trials were introduced or delayed, as it also depended whether the authorities were willing to follow the new fashion of c. 1500 to reinterpret any kind of witchcraft as a diabolic conspiracy and whether they saw reasons to adhere to the concept of the witches' sabbat, or agreed that witches could use demonic transport to such a meeting, the last two not necessarily simultaneously. Admittedly, these different waves of demonological interpretation only reached the British isles in fragmentary form; that they had no influence at all, however, is highly unlikely. This model of distribution is not discussed by Hutton, yet it explains why particular elements of the composite witch image arrived later than others in peripheral places. To apply 'the deeper perspective', as Hutton sometimes does instead, for instance in relation to the German-speaking lands, is unhelpful as there is basically no evidence for it. He merely repeats a number of times the image of the witch from early medieval law codes as a man-devouring female (p. 71), without indicating its importance or that it survived the later Middle Ages. Thus the suggestion that 'pre-existing beliefs in spirits that flew or rode by night would make that of the sabbath [sic] easier to adopt' (p. 203) is at best unsubstantiated and at worst plainly wrong. Likewise, Hutton's supposition that the narrative of temptation by the devil 'must have drawn on the common and widespread folk-tale motif of friendly spirits who encounter distressed human beings' (p. 203) is purely guesswork, overlooking the devil's relationship with heretics. Hutton fails to take into account here the earlier work of Richard Kieckhefer, in which the 'elite' culture of witchcraft is distinguished from its 'popular' culture.(11) This distinction has since been criticised; however, in the case of witchcraft there is no good reason to abandon it. In the early modern German lands, people in everyday village life certainly knew of the devil, but hardly ever connected him with witchcraft, nor did they have any notion of sabbats and flights. Torture, which helped to put these issues into the trial records, is eventually sidelined by Hutton as less decisive (p. 209) and countered with the remark that especially children could also reveal things spontaneously. Now and then they did indeed do so, but this takes nothing away from the thousands of instances of leading questioning and the enforced extraction of 
answers. Children form a point of attention on their own and they probably picked up their knowledge from what happened in neighbouring trials or what they were taught by their elders and teachers. As witnesses of events on daily life children were highly unreliable in this context.

The last chapter, about witches and animals, and in particular about the English witch's familiar, is in many respects the least convincing of the entire book. Not because the author admits that 'in last analysis the problem may actually not be susceptible to resolution' (p. 278), which is a refreshing admission, but because the way he gets there sums up once more the implausible approach Hutton adheres to. The reader is again confronted with the construct of 'contracting concentring circles of vision' (p. 264) and with the statement that (mainly 20th-century) non-European societies 'had no contact with each other'. Hutton overlooks the fact that most of them underwent colonialisation and Christianisation, not to mention that they all were investigated by anthropologists who had a (more or less) common western background. In this instance the question to ask about the anthropological material is, to what extent it was moulded and translated into an already present concept of the familiar by European (mostly English) reporters? When Hutton reaches early modern Europe, the 20th-century time frame is once more abandoned, but, unfortunately, so is precision and width of research. His assessment of shapeshifting across the continent is highly fragmentary, and the turning of flying mammals into 'real' animals is questionable (p. 269). Meanwhile, the solution to the familiar was staring him in the face. Originally a rare item of local folklore, possibly even of non-English origin, it became reinterpreted as a personal devil in the course of the 16th century. This was elaborated by news sheets and pamphlets in an early-modern instance of sensational reporting.(12)

Indeed, one of the problems of Hutton's book may well lie in the observation with which the above cited sentence about the 'last analysis' is concluded, namely that the development of 'different belief systems concerning magic and witchcraft (...) seem to have no obvious relationship with their political, social, economic and gender structures' (p. 278). Thus he seems to close the door to future research into just such contextualisation. It makes it hard, if not impossible to integrate witchcraft history into other histories. It is simply inconceivable that witchcraft, defined as an accusation of some people by others was situated outside social relationships (and Hutton's second characteristic points to that as well), much as it also must have touched on gender structures or politics, and, because it influenced economic produce, it is also hard to maintain that it had nothing to do with economy. Even if these 'belief systems' (another debatable term) evolved completely devoid of contexts, they will surely have had an effect on peoples' lives and the different ways they were structured. 
Leaving aside the discussion about the usefulness of anthropology in historical witchcraft research, The Witch keeps on circling around the European witch figure without hardly ever engaging with it. Certainly, the Romans knew witches, even prosecuted them, but these were unlike the late medieval witches more to the north. Shamans were never evil witches whatsoever and only in a very select number of cases can they be linked to service magicians and only when the definition of 'shaman' is stretched beyond its ethnographical limits. Egyptian magicians surely provided part of the repertoire of the medieval 'clerical underworld' (13), and they may also have inspired theologians to look for demonic pacts in the case of witches; magicians themselves were, however, hardly prosecuted. Some of the medieval 'Ladies of the Night' may have been able to creep through tiny holes, but again they were no witches. The chapter 'What the Middle Ages made of the witch' does not analyse the witch in everyday-life either (ceremonial magic is no witchcraft), nor does the next chapter. In part three of the book, where one would most expect a discussion of the witch, this is not forthcoming. Hutton comes the closest to such an analysis when he describes the bewitchment of milk (p. 248-50), but it is unsatisfactory without the necessary details as to why and how this was thought to happen, what was done against it and why especially women were accused of it. While throughout the book witches' crimes are described as 'alleged', Hutton does not pay attention to the process of ascription that will have preceded such an allegation and produced the 'witch'. After all, in a society where even saints were ascribed, such a process was far from strange. Imagination, in particular imagination 'within a tradition', was constantly treated as a prime reality and that the dominant ideology considered witchcraft as something real too, does not prove its historical accuracy and should not be accepted by the present-day researcher. There is no need to go native.

My criticism nevertheless should not take away from the fact that Hutton has given his readers abundant food for thought. His book will no doubt provoke ample and lively discussion and for that he should be congratulated.

\section{Notes}

1. Ronald Hutton, The Triumph of the Moon: A History of Modern Pagan Witchcraft (Oxford, 2001); idem, Shamans: Siberian Spirituality and the Western Imagination (London, 2001).Back to (1)

2. Among others: Ronald Hutton, 'The global context of the Scottish witch-hunt', in The Scottish WitchHunt in Context, ed. Julian Goodare (Manchester and New York, NY, 2002), 16-32; idem, 'Anthropological and historical approaches to witchcraft: potential for a new collaboration?', Historical Journal, 47 (2004), 413-34.Back to (2)

3. Especially Carlo Ginzburg, Storia Notturna (Turin, 1989), translated into English as Ecstasies (London, 1990). Back to (3)

4. Cf., f.i., Wolfgang Behringer, Witches and Witch-Hunts (Cambridge, 2004), p. 55, with Fritz Byloff, Hexenglaube und Hexenverfolgung in den österreichischen Alpenländern (Berlin/Leipzig, 1934), p. 19. Back to (4)

5. Precursors of the Witch's Sabbat, ed. Willem de Blécourt (Basingstoke, 2018).Back to (5)

6. Cf. Ronald Hutton, 'Witch-hunting in Celtic societies', Past and Present, 212 (2011), p. 43-71.Back to (6)

7. Alan Macfarlane, Witchcraft in Tudor and Stuart England: A Regional and Comparative Study (London, 1970). Back to (7)

$<$

8. Jeanne Favret-Saada, Les mots, la mort, les sorts (Paris,1977). In her latest work, Désorceler (Paris, 2009), she has isolated herself even more from witchcraft research, see: Willem de Blécourt, 'Contested knowledge: a historical anthropologist's approach to European witchcraft', in Cultures of Witchcraft in Europe from the Middle Ages to the Present, ed. Jonathan Barry, Owen Davies \& Cornelie Usborne (forthcoming, London, 2018).Back to (8)

9. Among others: Rolf Schulte, Man as Witch (Basingstoke, 2009).Back to (9) 
10. Lara Apps and Andrew Gow, Male Witches in Early Modern Europe (Manchester, 2003).Back to (10)

11. Richard Kieckhefer, European Witch Trials: Their Foundations in Popular and Learned Culture, 1300-1500 (London, 1976). Back to (11)

12. See also Michael Ostling and Richard Forest, "'Goblins, Owles and Sprites": discerning early-modern English preternatural beings through collational analysis', Religion, 44 (2014), p. 547-72.Back to (12)

13. The term is Kieckhefer's, see his Magic in the Middle Ages (Cambridge, 1990). Hutton does not use it. $\underline{\text { Back to (13) }}$

\section{Other reviews:}

Guardian

https://www.theguardian.com/books/2017/jul/28/witch-history-of-fear-ronald-hutton-review [3]

Spiral Nature

http://www.spiralnature.com/reviews/witch-ronald-hutton/ [4]

Source URL:https://reviews.history.ac.uk/review/2185

\section{Links}

[1] https://reviews.history.ac.uk/item/277404 [2] https://reviews.history.ac.uk/\%20\#f5

[3] https://www.theguardian.com/books/2017/jul/28/witch-history-of-fear-ronald-hutton-review

[4] http://www.spiralnature.com/reviews/witch-ronald-hutton/ 